\title{
Hydrodynamical control of phytoplankton succession during the vernal light-limited phase in the Baltic Sea
}

\author{
Sulev Nômmann, Ellen Kaasik \\ Institute of Ecology and Marine Research, Paldiski Rd 1, 200001 Tallinn, Estonia
}

\begin{abstract}
Phytoplankton, particle and hydrographical data from 2 consecutive springs $(1985,1986)$ collected from many areas of the Baltic Sea show that during the vernal light-limited phase most abundant spring bloom species can be divided into 3 successive groups, which grow rapidly under different environmental conditions: (1) monocellular autotrophic nanoflagellates; (2) small-cell centric diatoms; (3) other diatoms and dinoflagellates. Due to large-scale differences in the structure of the upper water column, the spring bloom temporal species succession may be converted to a basin-wide spatial distribution of subsequent phases, from the less stratified central part of the Baltic Sea to the stratified nearshore regions, the latter always being in a comparatively advanced stage. Special attention should be paid to the growth phase of small autotrophic flagellates, which may fill an important ecological 'niche' by affecting the total amount of inorganic nutrients incorporated into organic matter during the vernal bloom.
\end{abstract}

\section{INTRODUCTION}

The vernal phytoplankton of the Baltic Sea has been studied since the beginning of this century le.g. Välikangas 1926, Berzins 1932, Purasjoki 1947, Edler 1979b). The most thorough observations of the seasonal phytoplankton cycle have been made in coastal areas, especially near field stations like Tvärminne in Finland and Askö in Sweden (e.g. Hobro 1979, Niemi 1982). In the open parts of the Baltic Sea, investigations of the vernal bloom phenomenon as a whole have begun quite recently (Kaiser \& Schulz 1978, Bodungen et al. 1981, Leppänen 1988, Passow 1989, Kahru \& Nômmann 1990). The seasonal phytoplankton succession in the Baltic Sea is typically treated in 2 ways. Usually, the annual cycle has been partitioned into 6 or 7 periods or seasonal aspects (e.g. Hobro 1979, Piirsoo \& Porgasaar 1985); the other approach has been to divide the phytoplankton species into groups according to their coexistence (e.g. Edler 1979b).

The vernal aspect has been considered as the gradual development of a marine cold-water diatom assemblage (Chaetoceros wighamii, C. holsaticus, Achnanthes taeniata, Skeletonema costatum, Thalassiosira baltica and $T$. levanderi) together with a dinoflagellate (Gonyaulax catenata), after the onset of the seasonal thermocline (e.g. Nikolaev 1953, 1957. Niemi 1973). Usually these dominants are accompanied by some Arctic diatoms (such as Melosira arctica, Nitschia frigida, and Navicula vanhoeffeni). As shown by Alasaarela (1979), Kell (1981), Niems (1982) and others, this euryhaline assemblage tolerates salinities down to between 2 and $3 \%$ and usually occurs in a temperature range of 0 to $8{ }^{\circ} \mathrm{C}$.

Recent works by Niemi \& Åström (1987) in a coastal area and by Kahru \& Nômmann (1990) in the open Baltic proper offer reasons to reconsider the above scenario. In addition to Arctic diatoms and dinoflagellates, the vernal phytoplankton community contains several nanoflagellate groups (size $<15 \mu \mathrm{m}$ ) and also picoplankton $(<4 \mu \mathrm{m})$. A marked dominance of micro- and nanoplankton is observed in the coastal area already under the ice and during the turbulent stage of the bloom (Niemi \& Aström 1987) 
as well as in the central Baltic shortly before the outbreak of massive diatom 'flowering' (Kahru \& Nommann 1990). Contrary to the previous understanding, the vertical stability needed to trigger the commencement of the bloom is provided in the open Baltic proper by salinity- rather than temperaturerelated density stratification (Kahru \& Nommann 1990, Kahru et al. 1990). The development of the bloom is strongly influenced by inertial and subinertial hydrodynamical processes governed by meteorological conditions.

Results of the international patchiness experiment PEX '86 conducted under the auspices of ICES (1989) provide evidence that in the central Baltic, adjacent mesoscale water masses underwent individual patterns of spring bloom evolution which significantly differed from the mean over the PEX area as a whole (Kahru et al, 1990). The typical spring diatoms showed markedly different spatial patterns, and spatial variability of species distributions during the peak bloom phase was accentuated on the synoptic scale (Kononen et al. in press). The results indicate that hydrodynamic processes also determined the patch formations on the species level, and the bloom followed, in different synoptic-scale hydrodynamic formations, its specific life-history courses with particular phytoplankton assemblages.

The purpose of this study is to examine the trends in vernal phytoplankton succession in the open Baltic, in relation to the environmental background, before depletion of the nutrient resources in the upper mixed layer.

\section{OBSERVATIONS AND METHODS}

Most of the phytoplankton material was collected in April-May 1985 and 1986 from RV 'Arnold Veimer' while the ship was moving along a straight course at a constant speed. The transects, with additional discrete sampling spots, are shown in Fig. 1. Phytoplankton samples were 'picked' from flowing water (pumped from $5 \mathrm{~m}$ depth) in order to interpret the results of ongoing shipboard measurements of particle sizestructure and concentration, as well as in vivo chlorophyll fluorescence, in terms of phytoplankton assemblages with different hydrographical backgrounds. Particle number and size distribution were determined using an on-line particle size analyzer, HIAC-ROYCO PC-320 (see Pugh 1978), which counted particles from 1 to $1000 \mu \mathrm{m}$ (equivalent spherical diameter) in 12 size classes. In vivo fluorescence of chlorophyll pigments was measured from the same water with a TD 10-005 flow-through fluorometer. The operational details of the flow-through measurement system, as well as calibration procedures for the extracted chlorophyll a and microscopically identified phytoplankton, are thoroughly described in Kahru et al. (1989) and Kahru \& Nômmann (1990). A comparison of particle concentrations with phytoplankton total number determined from the same water is given in Fig. 2, showing that most of the particles in the size range 2 to $105 \mu \mathrm{m}$ are phytoplankton during the peak bloom phase in the open Baltic proper.

Simultaneously with the flow-through measurements, water temperature and conductivity at $5 \mathrm{~m}$

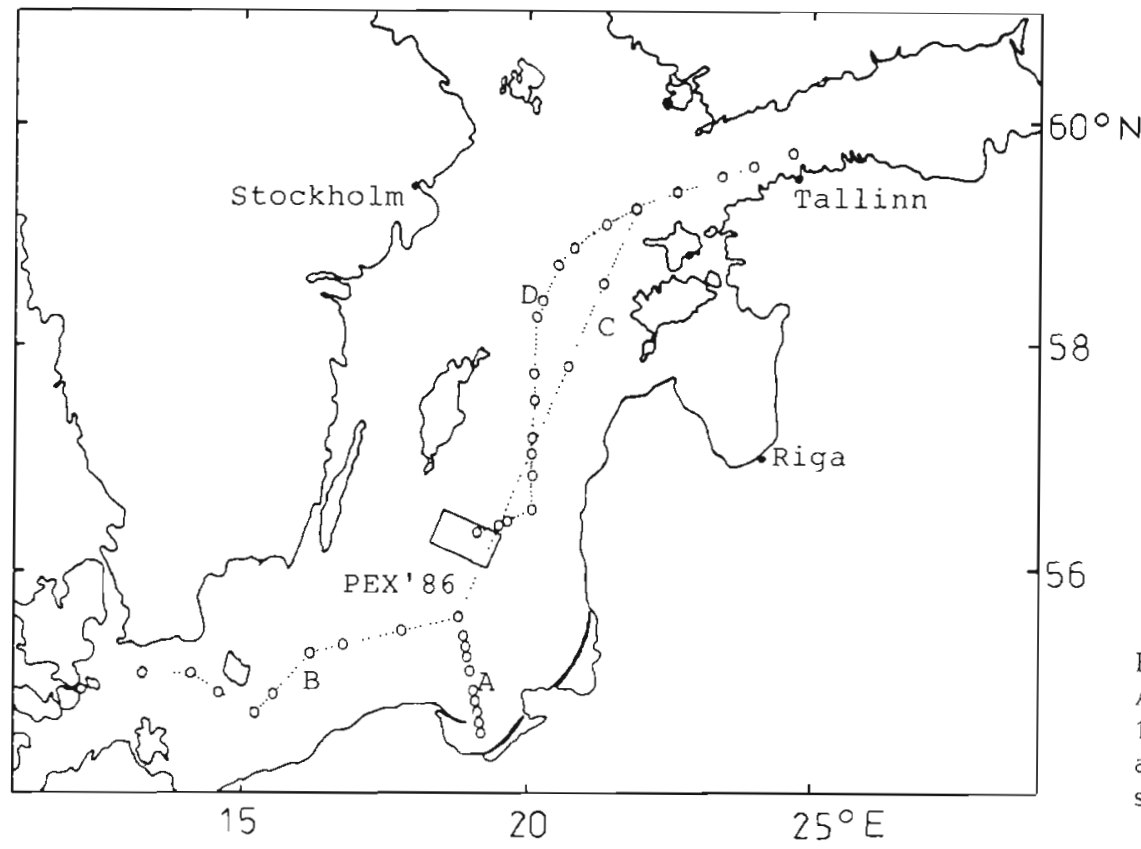

Fig. 1. Baltıc Sea, showing transects (A: 27 Apr 1985; B: 4-5 May 1985; C: 7-8 May 1985; D: 19-20 Apr 1986) of large-scale areal surveys, with additional discrete sampling locations $(0)$ and the PEX 86 polygon 


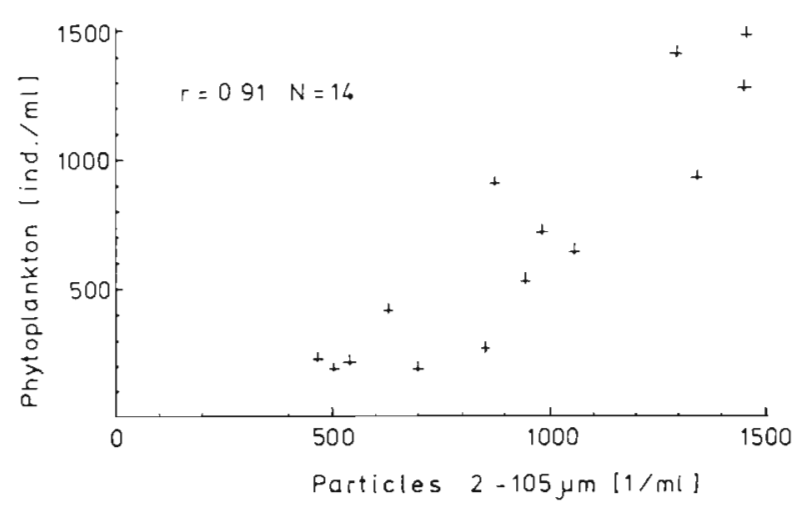

Fig. 2. Phytoplankton total number (counted as colonies, chains or solitary cells depending on species) versus total amount of particles in size range 2 to $105 \mu \mathrm{m}\left(\mathrm{no} . \mathrm{ml}^{-1}\right)$ determined from the same water

depth, as well as wind data, were recorded by the ship's automatic weather station. Calibrations of salinity were made with an Autosal salinometer and in the majority of cases the calculated salinities were reliably used as absolute values.

Several stations ca 30 nautical miles (nmi) apart were sampled by on-line measurement over a largescale section from the Gulf of Finland to the central Baltic; information on the vertical structure of the water column was obtained with a combination of a Neil Brown Mark lII CTD, a submersible EOS fluorometer and a rosette sampler. Some of the measurements were conducted together with synchronous undulating CTD soundings (described in ICES 1989), which gave valuable high-resolution (ca $0.5 \mathrm{nmi}$ ) information about the water column structure in the upper $80 \mathrm{~m}$ layer.

In addition, some inorganic nutrients $\left(\mathrm{NO}_{3}, \mathrm{PO}_{4}\right)$ were occasionally analyzed from flow-through water according to real-time particle distribution profiles on a PC computer screen, to assess the spring bloom stage in different open sea areas.

Samples for phytoplankton counts were preserved with Lugol's solution with acetic acid and analyzed using an inverted light microscope (Olympus Model IMT) according to Edler (1979a). Whenever possible, at least 100 chains or colonies of a particular dominant species were counted. Determination and counting of picoplanktonic organisms $<4 \mu \mathrm{m}$ size were unreliable under $400 \times$ magnification; also, most of the larger nanoflagellates were grouped as Pyramimonas spp. or Cryptomonas spp. within different size ranges. To avoid possible errors due to identification difficulties, combined cell numbers of Chaetoceros wighamil and C. holsaticus are presented as Chaetoceros spp.

In addition to the investigations made onboard RV 'Arnold Veimer', the phytoplankton and CTD data set collected during PEX ' 86 and distributed by ICES to all the participants was used to study the mechanisms controlling spring bloom species dynamics in different synoptic and smaller scale hydrodynamic formations (see study area in Fig. 1). The phytoplankton data collection during PEX ' 86 and methods applied in cell countings are described by Kononen et al. (in press). Mean salinity and temperature of the upper mixed layer (UML) were calculated from CTD vertical profiles with a $1 \mathrm{~m}$ depth resolution. The upper mixed layer depth (UMLD) was defined as the shallowest depth where a $0.02 \sigma_{\mathrm{t}}$ difference from the value at $5 \mathrm{~m}$ depth occurred, and also where the temperature difference from the value at $5 \mathrm{~m}$ depth exceeded $0.1^{\circ} \mathrm{C}$. The term 'mixed' implies homogeneity in the basic properties ( $T$ and $S$ ) of the water regardless of the density profile, so at a station the MLD would be the depth at which either $d T$ or dS first exceeds the selected limit of observational accuracy, indicating thereby the actual range of recent vertical excursions of phytoplankton due to short-term physical forcings (wave-mixing, thermal convection, etc.). Another definition for MLD would be the layer over which $\sigma_{1}$ varies less than the selected accuracy, i.e. the layer which can potentially be stirred with a minimum addition of energy. The latter definition has commonly been used for studies of phytoplankton which is physically confined to the surface layer by the underlying pycnocline.

An estimate of water column stability was made on the basis of seawater densities derived from CTD data by calculating the Väisälä frequency $(N)$ according to the formula

$$
N=\left[\left(g / p \times \mathrm{d} \sigma_{1} / \mathrm{d} z\right) \times 10^{-3}\right]^{0.5}
$$

where $g=$ acceleration due to gravity; $p=$ water density; and $z$ =depth. For this study, Väisälä frequencies were calculated over the $2 \mathrm{~m}$ depth interval immediately beneath the UML.

Daily totals of solar irradiance $\left(I_{0}\right)$ as well as irradiances in the water column $[/(z)]$ recorded onboard the RV 'Oceania' (Poland) (data by Dera and Sagan in ICES 1990) at the permanent anchor station during PEX '86 were used to follow the effects of light availability to phytoplankton cells in the UML. Vertical attenuation coefficients $(k)$ were calculated applying Lambert Beer's Law to pairs of PAR (photosynthetically active radiation) values at $1 \mathrm{~m}$ intervals over the upper $15 \mathrm{~m}$ layer (approximate depth of euphotic zone, determined optically), which thereafter were averaged. Since $I(z)$ measurements were not available for most of the PEX ' 86 stations, values for $k$ were approximated from Secchi depths $\left(Z_{\text {Secchi }}\right)$ using $k \approx Z_{\text {Seccnil }}{ }^{-0.57}$ (Tilzer 1988) instead of the generally accepted linear relationship $k=A / Z_{\text {Secchi, }}$ with $A$ varying between 1.4 and 2.0 (e.g. Pole \& Atkins 1929. Holmes 1970). The non-linear relationship used 
was derived from an analysis of $4 \mathrm{yr}$ of data from Lake Constance, Germany, which took into account the fact that Secchi depth is to a great extent a function of the beam attenuation of light, which differs from vertical light attenuation due to high sensitivity to scattering caused by phytoplankton particles (Tilzer 1988).

\section{RESULTS}

\section{Large-scale distributions of phytoplankton species, particle size groups and water properties}

Altogether 4 long transects along the axis of the Baltic Sea and from different basins (nearshore areas) towards the central Baltic are considered (see Fig. 1). Distributions of some particle size groups as well as the temperature and salinity at $5 \mathrm{~m}$ depth at these sections are presented in Kahru \& Nommann (1990) with the main emphasis on detailed description of the initiation of the vernal bloom in different regions of the Baltic Sea. Here we discuss the same transects from another point of view, emphasizing spatio-temporal aspects of the phytoplankton succession.

The first transect included the upper-layer phytoplankton and temperature salinity distributions from the Gdansk Bay northward to the southern Gotland Basin on 27 April 1985. Continuous measurements of salinity, temperature, chlorophyll and particles (Fig. 3A, B) show that the phytoplankton spring bloom was in a more advanced stage in the less saline (more stratified) and warmer Bay of Gdansk. The northern end of the section in the southern Gotland Basin could be considered as being still in the pre-bloom condition. The 3 typical phytoplankton spring bloom species, and different particle size groups, revealed different distribution patterns. While particles of 2 to $4 \mu \mathrm{m}$ size (unidentified) were almost linearly related to upperlayer salinity, the relationship of particles 28 to $42 \mu \mathrm{m}$ with salinity was quite complicated, whereas for particles from 42 to $73 \mu \mathrm{m}$ and 73 to $105 \mu \mathrm{m}$ a salinity value of $7.4 \%$ marked a definite boundary for high particle concentrations (Fig $3 \mathrm{C}$ to $\mathrm{F}$ ). Comparing particle data with phytoplankton counts during the spring bloom, particles from 42 to $73 \mu \mathrm{m}$ and 73 to $105 \mu \mathrm{m}$ included mainly Achnanthes taeniata chains of different lengths (see also Kahru et al. 1986), whereas smaller particle groups (e.g. 10 to $42 \mu \mathrm{m}$ ) represented a mixture of other abundant diatoms like Chaetoceros spp. and Skeletonema costatum. Thus, 3 successive stages in this transect could be observed: the winter water; 'patches' of rapidly growing species in areas with a relative salinity deficiency, in this case Chaetoceros spp.; and the bloom 'peak' stage, with high abun-
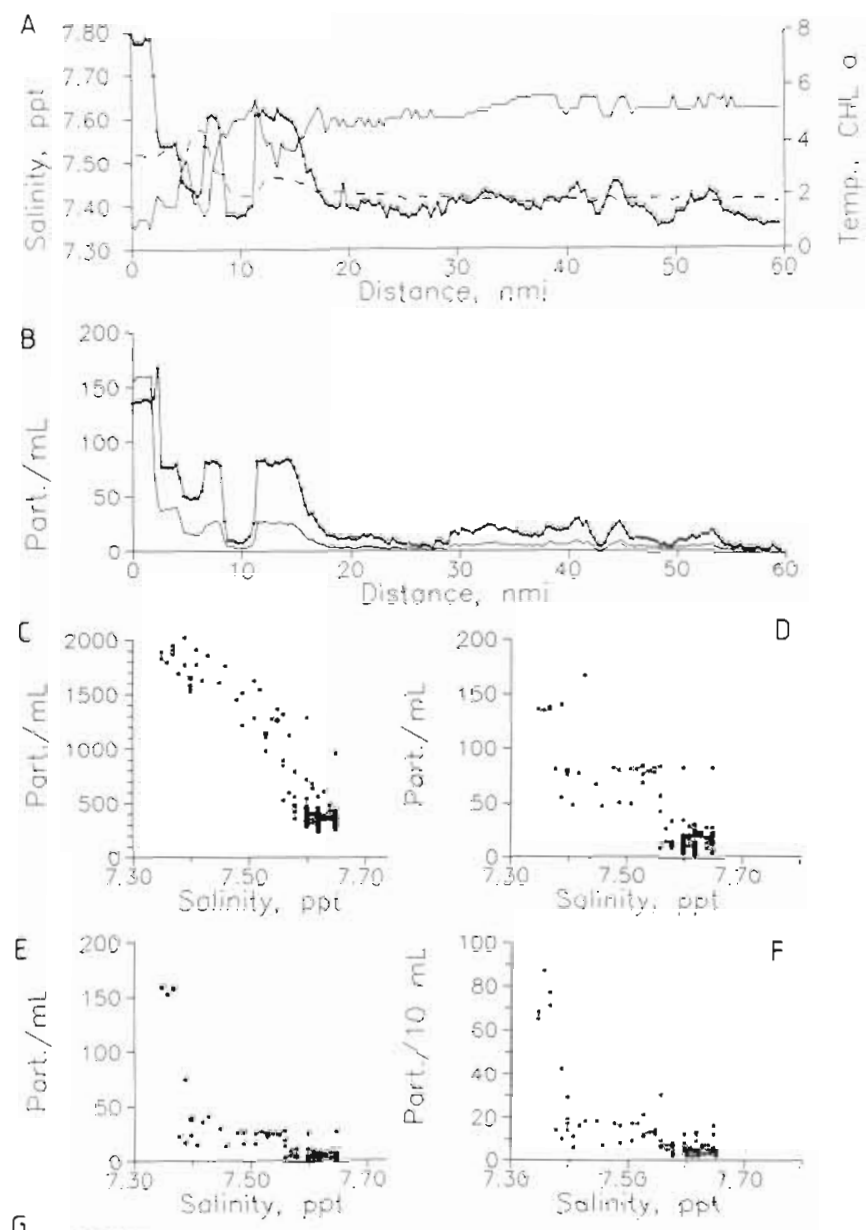



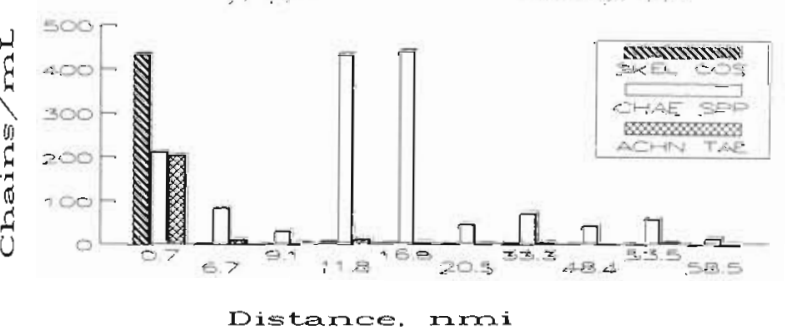

Fig. 3. Section of measurements from the Gdansk Bay northward to the southern Gotland Basin on 27 April 1985 (Fig. 1, Transect A.). All parameters measured or collected simultaneously at $5 \mathrm{~m}$ depth. (A) Distribution of salinity (-), temperature $\left({ }^{\circ} \mathrm{C}_{1}\right.$ - . - ) and chlorophyll a (-). (B) Distribution of particles (no. $\mathrm{ml}^{-1}$ ) 28 to $42 \mu \mathrm{m} \mathrm{(-)} \mathrm{and} 42$ to $73 \mu \mathrm{m} \mathrm{(-).}$ (C to F) Particles vs salinity, for particles of 2 to $4 \mu \mathrm{m}$ (C), 28 to $42 \mu \mathrm{m}$ (D), 42 to $73 \mu \mathrm{m}$ (E) and 73 to $105 \mu \mathrm{m}$ (F). (G) Distribution of 3 dominating phytoplankton species (Skeletonema costatum, Chaetoceros spp., Achnanthes taeniata; no. chains $\mathrm{ml}^{-1}$ ) along the same section. nmi: nautical miles (starting at the southernmost point of the transect)

dances of $A$. taeniata and $S$. costatum chains inside the Gdansk Bay, bounded by the salinity front (Fig. 3G).

The second transect (Fig. 4), from the Arkona Basin to the eastern Gotland Basin (central Baltic), sampled on 4-5 May 1985, covered the entire phytoplankton suc- 

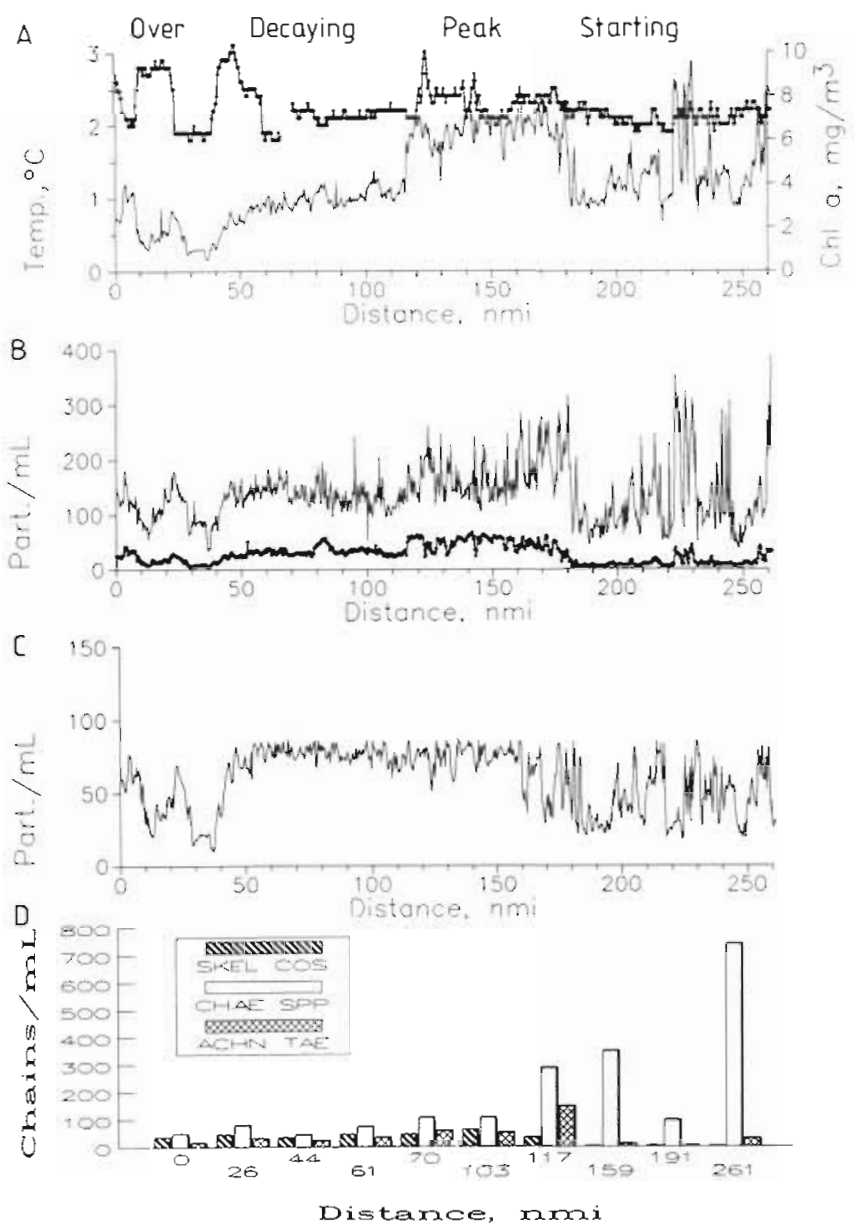

Fig. 4. Section of measurements from the Arkona Basin to the central Baltic on 4-5 May 1985 (Fig. 1, Transect B). All parameters measured or collected simultaneously at $5 \mathrm{~m}$ depth. (A) Distribution of temperature (- - ) and chlorophyll a (-), reflecting consecutive bloom phases in nearshoreoffshore direction. (B) Distribution of particles (no. $\mathrm{ml}^{-1}$ ) 10 to $20 \mu \mathrm{m}(-)$ and 42 to $73 \mu \mathrm{m}(-)$. (C) Distribution of particles 28 to $42 \mu \mathrm{m}$. (D) Distribution of 3 dominating phytoplankton species (Skeletonema costatum, Chaetoceros spp., Achnanthes taeniata; no. chains $\mathrm{ml}^{-1}$ ) along the same section. nmi: nautical miles (starting at the westernmost point of the transect)

cession: from the bloom initiation, with highly 'patchy' distributions of smaller diatoms (Chaetoceros spp.) in the southern Gotland Basin, until the already decaying phase of the bloom in the Arkona Basin. Unfortunately, we obtained only 1 phytoplankton sample representing the area with the heaviest bloom. However, distributions of species in the onshore-offshore direction were similar to these in the previous transect.

The same distributions and relationships as in the first transect, but from the Gulf of Finland to the central Baltic on 7-8 May 1985 and 19-20 April 1986, are shown in Figs. $5 \& 6$ respectively. The overall features of these sections were the same as in the transect from

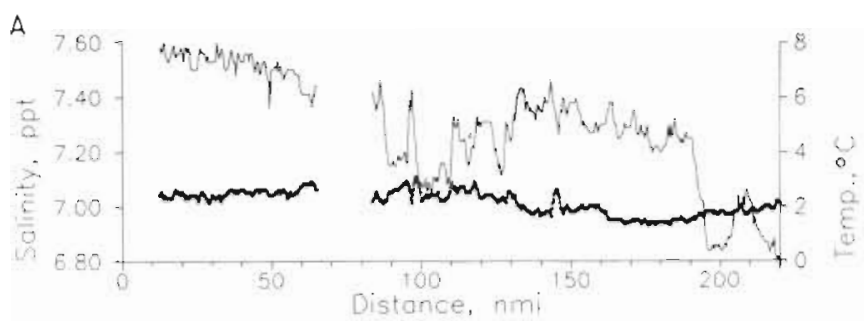

B
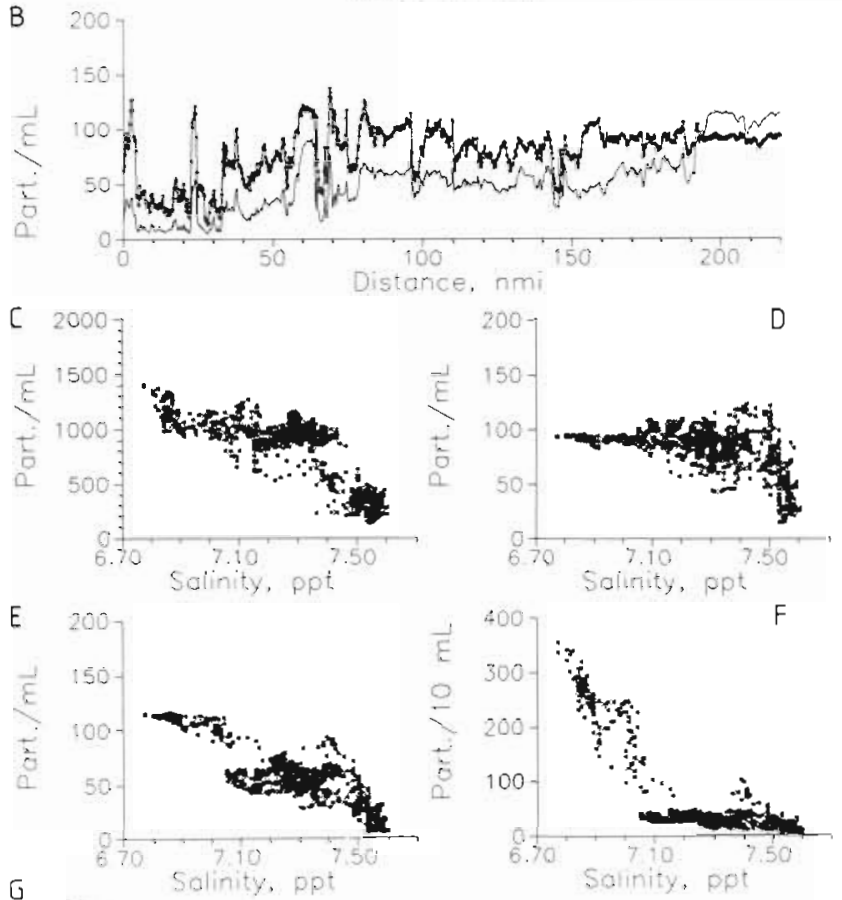

G

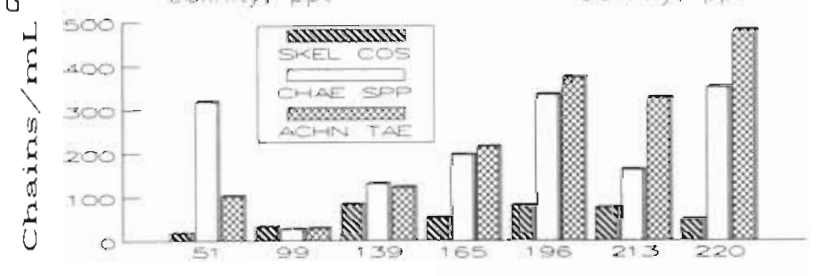

Distance, xuxni

Fig. 5. Section of measurements from the Gulf of Finland to the Central Baltic on 7-8 May 1985 (Fig. 1, Transect C). All parameters measured or collected simultaneously at $5 \mathrm{~m}$ depth. (A) Distribution of salinity $(-)$ and temperature $(-$ ). (B) Distribution of particles 28 to $42 \mu \mathrm{m} \mathrm{( \longmapsto )} \mathrm{and} 42$ to $73 \mu \mathrm{m}$ (-). (C to F) Particles vs salinity, for particles of 2 to $4 \mu \mathrm{m}(\mathrm{C})$, 28 to $42 \mu \mathrm{m}$ (D), 42 to $73 \mu \mathrm{m}$ (E) and 73 to $105 \mu \mathrm{m}$ (F). (G) Distribution of 3 dominating phytoplankton species (Skeletonema costatum, Chaetoceros spp., Achnanthes taeniata; no. chains $\mathrm{ml}^{-1}$ ) along the same section nmi: nautical miles (ending at the easternmost point in the Gulf of Finland)

the Gdansk Bay to the central Baltic. The bloom was in a comparatively advanced stage towards the stratified waters of the Gulf of Finland and had just begun, in the form of filaments, in the open northern Baltic proper. The areas between the initial patches were still in prebloom conditions. Comparing Figs. 3B and 5B, both for 
$\Delta$
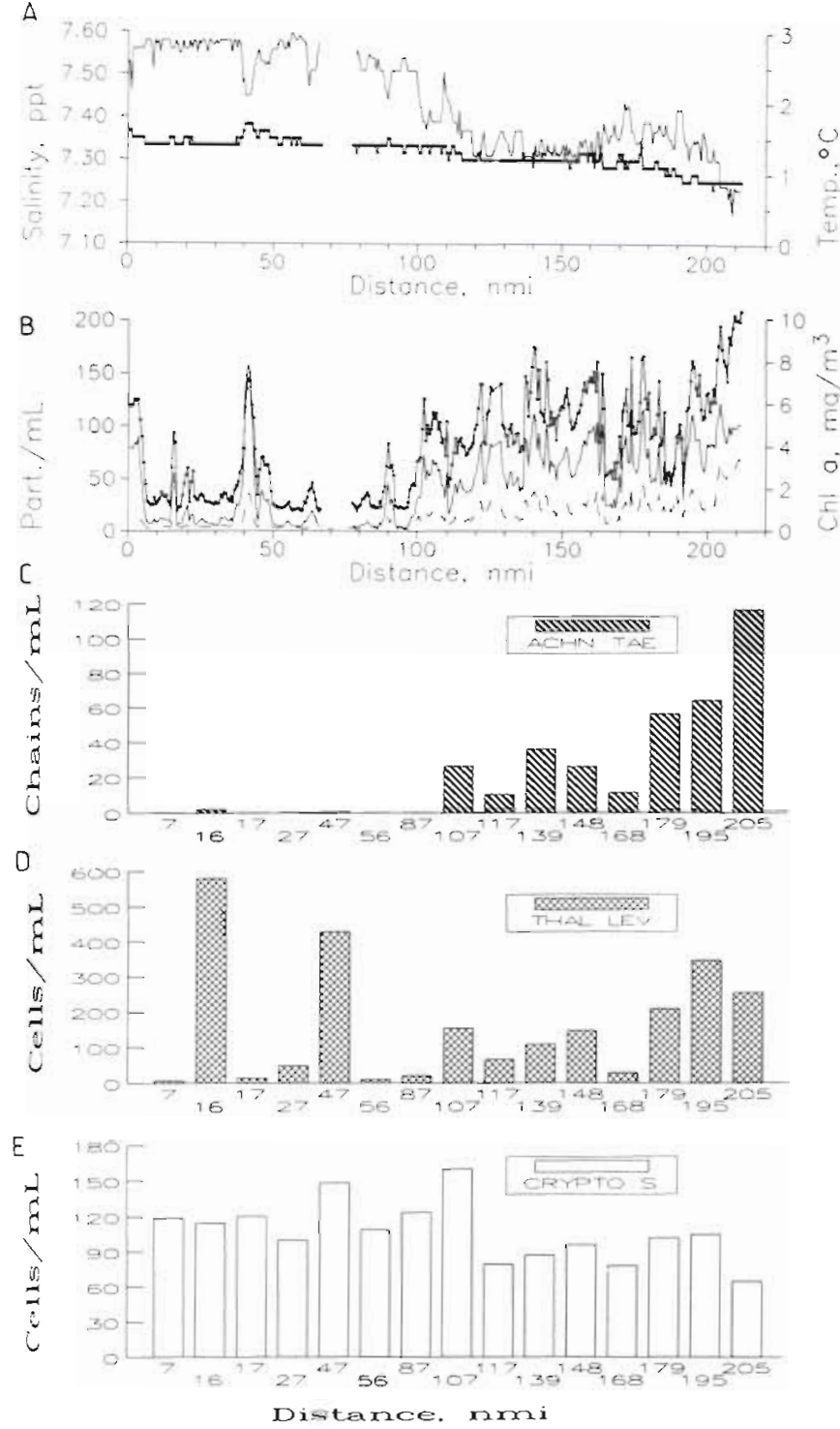

Fig. 6. Section of measurements from the Gulf of Finland to the central Baltic on 19-20 1pril 1986 (Fig. 1, Transect D). All parameters mcasured or collected simultaneously at $5 \mathrm{~m}$ depth. (A) Distribution of salinity ( - ) and temperature ( - ). (B) Distribution of particles (no. $\mathrm{m}^{-1}$ ) 28 to $42 \mu \mathrm{m} \mathrm{( \longrightarrow )} \mathrm{and}$ 42 to $73 \mu \mathrm{m}$ (- - - ), and chlorophyll a (-) . (C to E) Phytoplankton distribution: (C) Achnanthes taeniata chains, (D) Thalassiosira levanderi cells, (E) nanoflagellates Cryptomonas spp. nmi: nautical miles (ending at the easternmost point in the Gulf of Finland]

the waters of the Gulf of Finland and the Gdansk Bay, the absolute numbers of particles from 42 to $73 \mu \mathrm{m}$ dominate over those in the next smaller size class ( 28 to $42 \mu \mathrm{m})$. This may indicate an absolute predominance of the Achnanthes taeniata chains. A striking feature is the bimodal relationship of salinity and particles 73 to $105 \mu \mathrm{m}$ in size (Fig. 5F), consisting almost entirely of longer A. taeniata chains. As reported earlier (Kahru et al. 1986), the salinity front at the entrance to the Gulf of Finland marked a boundary between the phytoplankton communities in different developmental stages, which were characterized, for instance, by various lengths of the dominating $A$. taeniata chains.

As seen in Figs. $5 \& 6$, all the boundaries where the major changes in the dominance structure of phytoplankton communities occurred are related to quasistationary salinity fronts, which eventually divide the open sea into large-scale sub-basins (see Elken et al. 1987, Pavelson 1988). Hydrographic data, nutrient concentrations and the phytoplankton abundances representative of both sides of the salinity front (in Fig. $6 \mathrm{~A}$ at ca $100 \mathrm{nmi}$ ) and of diatom filaments at 2 locations with relative salinity deficiency in the open northern Baltic proper in April 1986 are given in Table 1. It becomes evident that, although nowhere on that section were the nutrients limiting, the bloom on the northern side of the front was in a more advanced stage (compare nutrient concentrations in Table 1). CTD soundings taken ca $30 \mathrm{nmi}$ apart, starting from the Gulf of Finland, revealed that almost everywhere in the open northern Baltic proper (north of the front) the thickness of the UML was restricted to ca 20 to $30 \mathrm{~m}$ due to strong salinity stratification. South of the front the mixed layer occasionally reached down to the main halocline. On a very broad scale, from the Gulf of Finland to the central Baltic, upper-layer salinity apparently provided a simple predictor for UML thickness (Fig. 7C). Fig. 7D to F shows how the 3 most common species were related to UML depth in this section. While Cryptomonas spp. occurred in higher abundances in deeply mixed 'winter' water, high numbers of Achnanthes taeniata cells occurred only in regions with a rather shallow UML, whereas increasing numbers of Thalassiosira levanderi cells could be observed in upper layers mixed down to $40-50 \mathrm{~m}$. For comparison with the other transects, the relationship of particles 42 to $73 \mu \mathrm{m}$ in size with upper-layer salinity and the number of A. taeniata chains is shown in Fig. 7A, B.

\section{Phytoplankton succession in mesoscale water masses}

Kononen et al. (in press) have found that different successional stages of the phytoplankton community can occur simultaneously in adjacent synoptic-scale water masses. Here, further findings on the background conditions necessary for the development of these different stages are presented and the possible triggering mechanisms discussed.

An example of the phytoplankton species distribution in the PEX area in relation to the upper-watercolumn density structure and the concentration of nitrogenous nutrients $\left(\mathrm{NO}_{3}+\mathrm{NO}_{2}\right)$ is presented in 
Table 1. Large-scale spatial distribution of hydrographic data, inorganic nutrients and phytoplankton cell numbers to the north and south of the salinity front at 100 nautical miles in Fig. 6 and in diatom filaments at 2 locations in the central Baltic, $19-20$ April 1986. nmi: nautical miles; UMLD: upper mixed layer depth

\begin{tabular}{|c|c|c|c|c|}
\hline \multirow[t]{2}{*}{ Variable } & \multirow{2}{*}{$\begin{array}{c}\text { North } \\
\left(\text { Mean } \pm S D^{a}\right)\end{array}$} & \multirow{2}{*}{$\begin{array}{c}\text { South } \\
\text { (Mean } \pm S D ")\end{array}$} & \multicolumn{2}{|c|}{ Filaments at: } \\
\hline & & & $16 \mathrm{nmi}$ & $47 \mathrm{nmi}$ \\
\hline Temperature $\left({ }^{\circ} \mathrm{C}\right)$ & $1.19 \pm 0.12$ & $1.41 \pm 0.04$ & 1.5 & 1.6 \\
\hline Salinity (ppt) & $7.35 \pm 0.04$ & $7.55 \pm 0.03$ & 7.54 & 7.52 \\
\hline $\operatorname{UMLD}(\mathrm{m})$ & $20-30$ & $30->60$ & & \\
\hline $\mathrm{NO}_{3}\left(\mu \mathrm{mol} \mathrm{l}{ }^{-1}\right)$ & $3.36 \pm 0.96$ & $4.53 \pm 0.31$ & 3.36 & 4.53 \\
\hline $\mathrm{PO}_{4}\left(\mu \mathrm{mol} \mathrm{I}^{-1}\right)$ & $0.35 \pm 0.09$ & $0.50 \pm 0.08$ & 0.42 & 0.35 \\
\hline \multicolumn{5}{|l|}{ Phytoplankton $\left.\left(10^{3} \text { cells }\right)^{-1}\right)$} \\
\hline Cryptomonas spp. $(5-7 \mu \mathrm{m})$ & 53 & 59 & 57 & 90 \\
\hline Cryptomonas spp. $(12-15 \mu \mathrm{m})$ & 44 & 55 & 57 & 59 \\
\hline cf. Eutreptia spp. $(25 \mu \mathrm{m})$ & 3.5 & 4.1 & 9 & 8 \\
\hline Thalassiosira levanderi & 167 & 20 & 584 & 431 \\
\hline Chaetoceros spp. & 525 & 29 & 763 & 135 \\
\hline Pyramimonas spp. & 215 & 41 & 30 & 210 \\
\hline Achnanthes taeniata & 476 & 1.3 & 21 & 6 \\
\hline Skeletonema costatum & 8.5 & 0.08 & 7 & 0.6 \\
\hline Thalassiosira baltica & 1.0 & 0.07 & 0.8 & 0.2 \\
\hline Gonyaulax catenata & 2.2 & 0 & 0.5 & 0.4 \\
\hline Gymnodinium sp. $(30 \mu \mathrm{m})$ & 93 & 3.2 & 7 & 3 \\
\hline
\end{tabular}

Fig. 8. Because of a $12 \mathrm{~h}$ lag between the discrete samplings from stations (phytoplankton, nutrients) and the on-line CTD measurements with the undulating probe along the same track, the distributions of 2 size groups of particles measured synchronously with the towed CTD probe are also presented, allowing a better combination of the information from both the biological and physical studies. Dense patches of Thalassiosira levanderi and Chaetoceros spp. correspond well to a pair of mesoscale anticyclonic and cyclonic eddies (seen in the density profile in Fig. 8E). The most remarkable feature in this section is the presence of small particle ( 4 to $6 \mu \mathrm{m}$ ) peaks, precisely in the region where the isopycnals are virtually vertical, nutrient concentrations are close to winter levels and the diatom size fraction ( 28 to $42 \mu \mathrm{m}$ ) is at a minimum (arrows in Fig. 8D). The low-resolution sampling of phytoplankton does not resolve these fine-scale processes except in the continuous particle countings. However, the sample from $12 \mathrm{nmi}$ appeared to be representative of the patch in the narrow deep mixing zone between eddies, displaying high numbers of the nanoflagellate Pyramimonas spp. (cf. virginica). To the east of the cyclonic eddy in the strongest frontal area, such a Pyramimonas patch is missing. The explanation for this could be that here the water from much deeper layers (below $50 \mathrm{~m}$ ) is more intensively transported along the isopycnals to the surface (Fig. 8E).

Numerous studies carried out in marine environments have shown a close relationship between the occurrence of diatom blooms and the establishment of density stratification in the water column (e.g. Pingree et al. 1976, Sambrotto et al. 1986). A close correlation between the rate of phytoplankton population increase and the reciprocal of UML depth was reported long ago (Riley 1942). Therefore, to evaluate the importance of upper-water-column properties for growth of the dominant diatoms (nanoflagellates were only sporadically counted during PEX) in the central Baltic, the logtransformed abundances of 4 species (Chaetoceros spp., Thalassiosira levanderi, Achnanthes taeniata, Skeletonema costatum), UML thickness, mean temperature and salinity as well as stability (Väisälä frequency), calculated on the basis of CTD profiles, were subjected to linear correlation analysis (Table 2). To avoid the biasing effects of the bloom transition from light-limited to nutrient-limited conditions, only the phytoplankton data from $5 \mathrm{~m}$ depth (representative of the UML) and CTD profiles from the same station grids on 4 consecutive days during the April study period (i.e. before development of the seasonal thermocline) were used for the analysis. Nutrients were excluded from the analysis, since they were abundant throughout the April investigation period (Kahru et al. 1990).

Most of the statistically significant correlation coefficients were relatively low (Table 2), indicating the complexity of links in the pelagic ecosystem. It appears that the causal relationship between phytoplankton stock size and water column structure is not always obvious. In the Baltic, it is not likely that a close relationship 


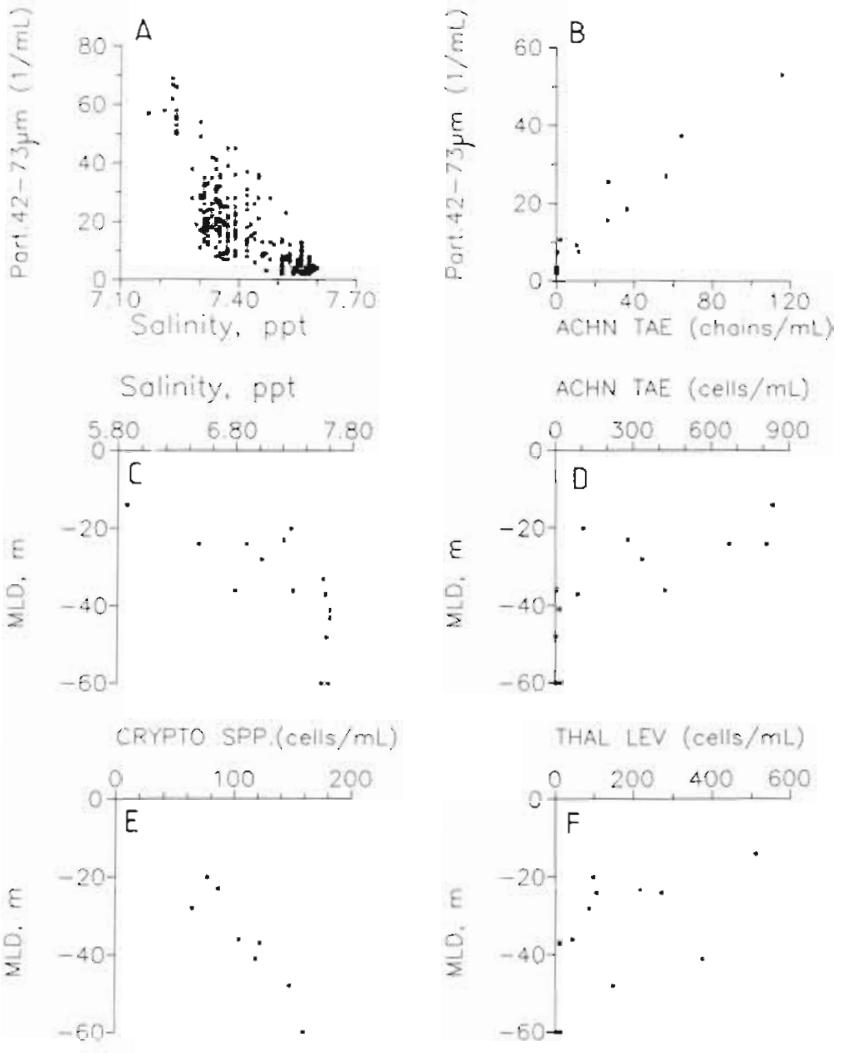

Fig. 7. Relationships between different variables measured on the transect from the Gulf of Finland to the central Baltic on 19-20 April 1986. (A) Particles 42 to $73 \mu \mathrm{m}\left(\mathrm{no} . \mathrm{ml}^{-1}\right.$ ) vs salini.ty. (B) Particles 42 to $73 \mu \mathrm{m}$ (no. $\mathrm{ml}^{-1}$ ) vs Achnanthes taeniata chains (no. $\mathrm{ml}^{-1}$ ). (C) Upper-layer salinity vs upper mixed layer depth. (D to F) Abundance of diatoms vs upper mixed layer depth: (D) A. taeniata, (E) Cryptomonas spp.,

(F) Thalassiosira levanderi

exists between phytoplankton growth and mixing depth within small areas of the sea surface. Vertical upward and downward flows may occur over a distance along the isopycnal surfaces from depths, unpredictable by means of single vertical CTD profiles (e.g. see Fig. 8E).

For a better understanding of the system's functioning, we followed the 4 phytoplankton species' growth in distinct water masses separately (Figs. $9 \& 10$ ). One should be aware of diffusive and advective effects, which can greatly complicate studies of phytoplankton community development. Fortunately, the long-term mean currents over the shallow western slope of the Gotland Deep were negligible, and the evolution of the overall hydrographical pattern relative to the sampling frequency was slow (ICES 1989). Time series of the 4 phytoplankton species' abundances and different environmental factors in 2 selected water masses - the shallow (mean depth ca $20 \mathrm{~m}$ ) and less saline $(<7.5 \%)$ water mass on the western slope of the Gotland Deep and the water mass inside the anticyclonic eddy (ICES 1989) - included 2 of the most critical parameters for
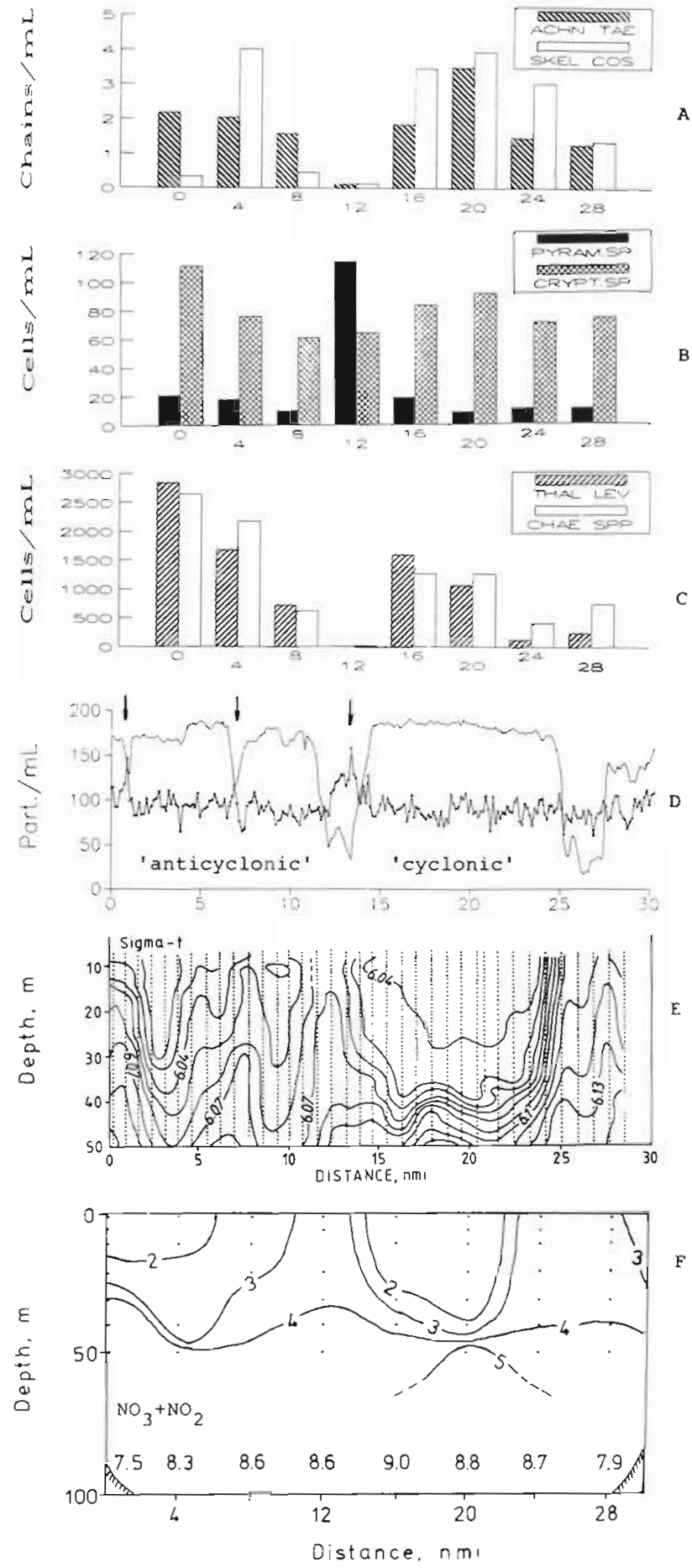

Fig. 8. Distributions of different phytoplankton species [(A) Achnanthes taeniata, Skeletonema costatum; (B) Pyramimonas spp., Cryptomonas spp.; (C) Thalassiosira levanderi, Chaetoceros spp.] and nitrogenous nutrients [(F); $\mathrm{NO}_{2}+\mathrm{NO}_{3}$ $\mu \mathrm{M} \mathrm{I}^{-1}$ ] in the PEX ' 86 polygon (see Fig. 1) on 25 April 1986, compared with particle profiles measured synchronously at $5 \mathrm{~m}$ depth, $12 \mathrm{~h}$ after the phytoplankton measurements [(D); 28 to $42 \mu \mathrm{m}(-), 4$ to $6 \mu \mathrm{m}(-$ ) ], and vertical density profile $(E)$. The density profile was kindly provided by M. Pajuste, and the nutrient protile by T. Pôder 
Table 2. Correlation matrix between phytoplankton (log-transformed) and physical variables (performed for the PEX ' 86 data set from 25 to 28 April $1986 ; n=246$

\begin{tabular}{|c|c|c|c|c|c|c|c|c|c|}
\hline & (1) & (2) & (3) & (4) & (5) & (6) & (7) & $(8)$ & (9) \\
\hline (1) Achnanthes taeniata & 1.00 & & & & & & & & \\
\hline (2) Chaetoceros spp. & $0.63^{\circ}$ & 1.00 & & & & & & & \\
\hline (3) Skeletonema costatum & $0.62^{\circ}$ & $0.46^{\circ}$ & 1.00 & & & & & & \\
\hline (4) Thalassiosira levanderi & $0.72^{\bullet}$ & $0.59^{\circ}$ & $0.48^{\circ}$ & 1.00 & & & & & \\
\hline (5) $\mathrm{MLD}^{\mathrm{a}}$ & $-0.18^{\circ}$ & $-0.27^{\bullet}$ & -0.10 & 0.02 & 1.00 & & & & \\
\hline (6) $\mathrm{MLD}^{\mathrm{b}}$ & $-0.29^{\circ}$ & $-0.32^{\circ}$ & $-0.21^{\cdot}$ & $-0.27^{\circ}$ & $0.51^{\bullet}$ & 1.00 & & & \\
\hline (7) Temperature & $0.42^{\bullet}$ & $0.32^{*}$ & $0.28^{\bullet}$ & $0.40^{\circ}$ & $-0.24^{\bullet}$ & $-0.59^{\circ}$ & 1.00 & & \\
\hline (8) Salinity & -0.07 & -0.14 & -0.05 & $0.22^{\circ}$ & $0.56^{\circ}$ & $0.22^{\bullet}$ & -0.09 & 1.00 & \\
\hline (9) $N^{c}$ & 0.12 & 0.16 & 0.03 & $0.20^{\circ}$ & $0.40^{\circ}$ & $0.21^{\circ}$ & 0.14 & -0.04 & 1.00 \\
\hline \multicolumn{10}{|c|}{$\begin{array}{l}{ }^{a} \text { Upper mixed layer depth according to } \mathrm{d} \sigma_{\mathrm{t}}>0.02 \mathrm{units}^{-1} \mathrm{~m}^{-1} \\
{ }^{\mathrm{b}} \text { Upper mixed layer depth according to } \mathrm{d} T>0.1^{\circ} \mathrm{C} \mathrm{m}^{-1} \\
{ }^{\mathrm{C}} \text { Väisälä frequency immediately beneath the upper mixed layer } \\
{ }^{\circ} \mathrm{p}<0.01\end{array}$} \\
\hline
\end{tabular}

phytoplankton growth: daily totals of solar irradiation and an assessment of the depth of the phytoplankton vertical excursions due to wind mixing.

The depth of wind-induced wave mixing $\left(H_{p}\right)$ in the UML was calculated according to the empirical equation (Fennel et al. 1986)

$$
H_{\mathrm{p}}=C \times V_{\mathrm{w}}{ }^{3 / 2},
$$

where $C=1.3 \mathrm{~s}(\mathrm{~s} / \mathrm{m})^{1 / 2}$ and $V=$ velocity of the local wind.

Because of a gap in the phytoplankton data set from 29 April until 3 May, a chlorophyll time-series redrawn from Kahru et al. (1990) is given (Fig. 9F) to provide a realistic perspective of the bloom dynamics in the shallow western water mass. The time-series in the second water body covers only the first half of the PEX study period, because the anticyclonic eddy disintegrated around 1 May.

A closer comparison of time-series results for the 2 adjacent water bodies reveals that on average, UML thickness in the shallow western area was ca $10 \mathrm{~m}$ less than in the anticyclonic eddy during the entire period. Both water masses reached the temperature of maximum water density (about $2.35^{\circ} \mathrm{C}$ at a salinity of $7.5 \%$ ) on 29 April, after which the formation of the seasonal thermocline could be observed. Higher incoming solar radiation values at the beginning of May led to a rapid increase in the upper-layer temperature and a remarkable shoaling of the UML after 2 May.

At the beginning of the observation period the abundances of Chaetoceros spp. and Thalassiosira levanderi in the anticyclonic eddy were almost 1 order of magnitude higher than in the shallow western area. Neighboring localities shared essentially the same weather and solar radiation at the sea surface but differed in their topography. Stronger wind events on 24-25 April, as well as earlier ones (not shown), caused wave-induced mixing down to the bottom (Fig. 9E) in the shallow western area, most probably leading to resuspension of sediments (reduced Secchi depths relative to those in deeper pre-bloom waters) and therefore affecting light penetration into the water column there. Thus the onset of the bloom in this area seems to have been impeded.

Beginning with calm weather and low wave mixing on 26-27 April, the abundance of all 4 diatom species indicated growth in the shallow western area. In the anticyclonic eddy low incoming radiation on 25 to 27 April resulted in a decrease in abundances of Thalassiosira levanderi and Chaetoceros spp. due to sedimentation (see Passow 1989), whereas abundances of Achnanthes taeniata stayed at the same low level. The main discrepancy in temporal patterns among the 4 selected diatoms lay in the conditions when peak abundance was attained. Chaetoceros spp. and T. levanderi reached very high cell numbers already before the development of a seasonal thermocline in the UML, ca 30 to $40 \mathrm{~m}$ thick. Blooming of $A$. taeniata and Skeletonema costatum could be observed only after general shoaling of the UML due to the onset of a thermocline. Thus, the same succession as found spatially in the onshore-offshore direction on a larger scale occurred over time in the central Baltic in mesoscale water masses during the light-limited phase of the bloom.

Finally, an attempt was made to represent the empirically determined critical light regime in the UML for the 4 selected diatoms (Fig. 11). Mean light intensity in the mixed layer of a given well-defined water mass was estimated using the following equation (Riley 1957):

$$
I=I_{o}\left(1-\mathrm{e}^{-k z}\right) / k z,
$$



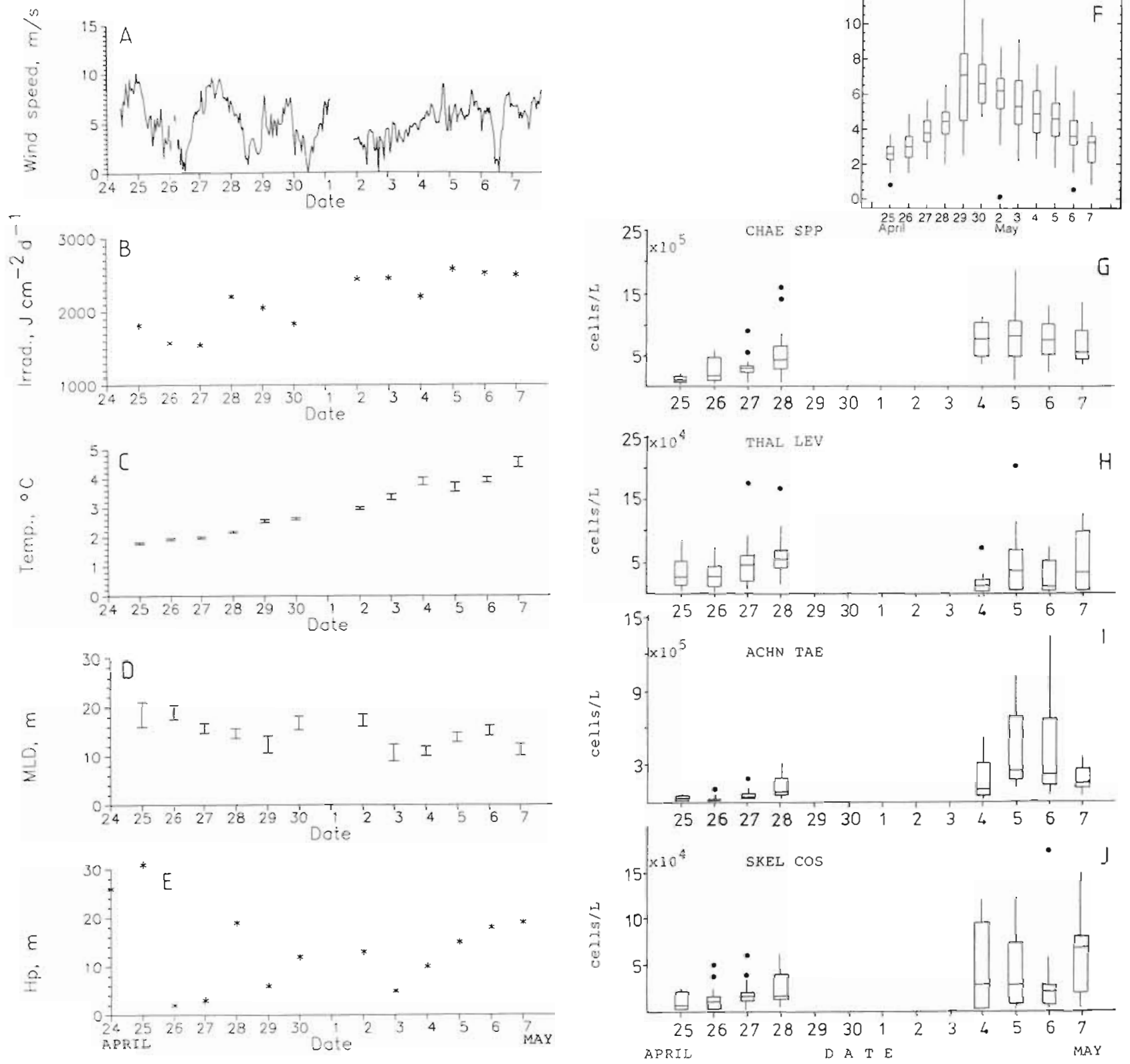

Fig. 9. Time-series measurements of (A) wind speed, (B) daily totals of solar irradiation, (C) upper mixed layer mean temperature \pm standard error of estimate (SEE), (D) upper mixed layer depth \pm SEE, (E) depth of wind-induced wave-mixing (see explanations in text), (F) chlorophyll a (panel redrawn from Kahru et al. 1990), and cell numbers of (G) Chaetoceros spp., (H) Thalassiosira levanderi, (I) Achnanthes taeniata and (J) Skeletonema costatum in the western shallow water mass in the PEX ' $86 \mathrm{study}$ area. In (G) to $(\mathrm{J})$, the central box covers the middle $50 \%$ of data values, between the upper and lower quartiles; central line is the median; bars extend to the upper/lower quartile $\pm 3 \times$ interquartile range; extreme values are plotted as separate points

where $I_{o}=$ daily total of solar irradiation, $k=$ coefficient of extinction and $z=$ depth of the upper mixed layer. On the basis of phytoplankton abundance on consecutive days, relative growth rates in the same water mass were calculated according to the formula (Knoechel \& Kalff 1978)

$$
k=\ln \left(N_{t} / N_{0}\right) / t_{1}
$$

where $N_{t}$ and $N_{0}$ are phytoplankton cell numbers in the UML at Day $t$ and Day 0. Gains and losses due to advection within a certain water mass cancelled out, since the calculation of relative growth rate was based on phytoplankton abundance averaged horizontally and vertically over the whole UML of the water mass. As the abundance of main mesozooplankton grazers 


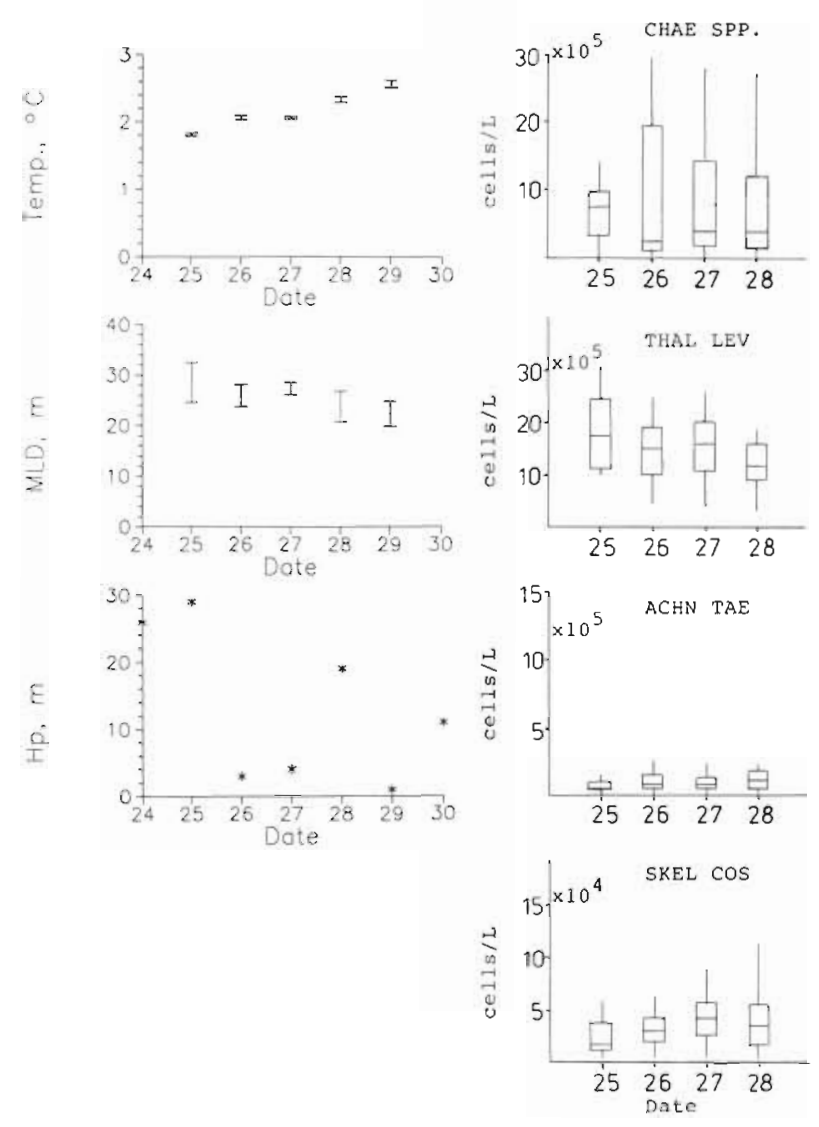

Fig. 10. Time-series measurements of the same variables as in Fig. 9, but for the anticyclonic eddy in the PEX ' 86 study area
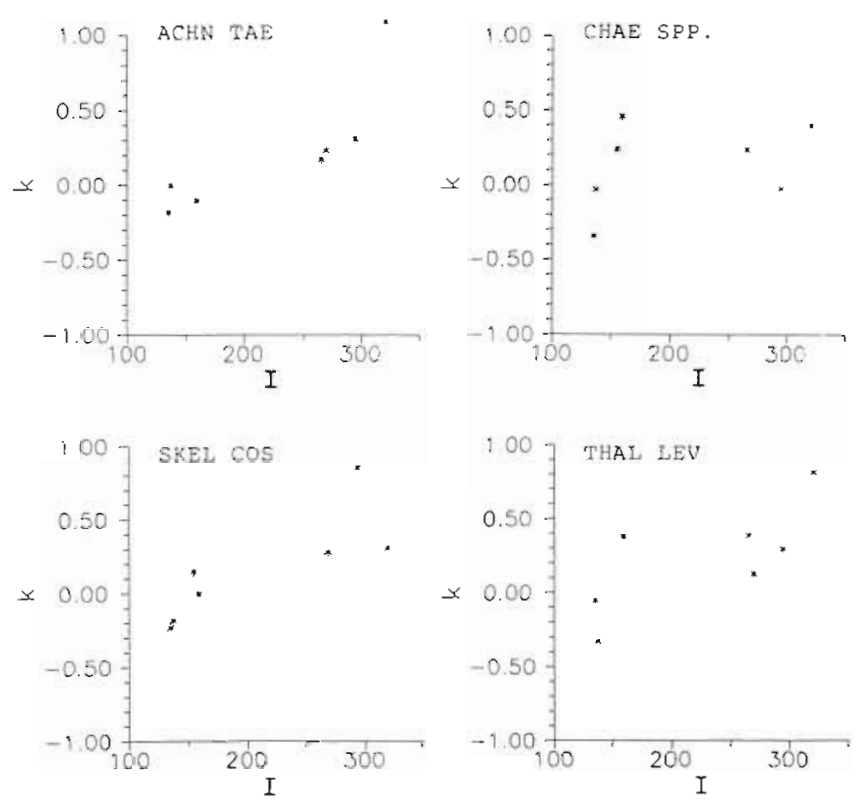

Fig. 11. Relative growth rate (k) versus mean light intensity in the mixed layer $\left(I, \mathrm{~J} \mathrm{~cm}^{-2} \mathrm{~d}^{-1}\right.$ ) determined empirically for the 4 typical spring bloom diatoms in the PEX ' 86 study area: Achnanthes taeniata, Chaetoceros spp., Skeletonema costatum, Thalassiosira levanderi during the PEX period was relatively low (ICES 1989) and intensive sedimentation of these phytoplankton species was not observed before the end of April (Passow 1989), one can assume that for the first days of the investigation, sinking and grazing losses for any particular species were negligible. In Fig. 11, there are too few data points to recommend a statistical approach, but the distribution of points seems to indicate a coupling between the actual light regime and the growth rates: for growth of A. taeniata, higher light intensities are needed than for Chaetoceros spp. and $T$. levanderi

\section{DISCUSSION}

The term 'succession' implies some directional, nonrandom sequence of phytoplankton species alternation in time (Margalef 1958, 1967). Generally, species succession occurs when physiological adaptation is no longer sufficient to provide a competitive advantage for a given species (Falkowski 1984). Autecological studies have provided insight into the ability of a given species to adapt to various regimes, but such information is of limited value in predicting species succession unless the environmental conditions experienced by the organism in natural systems are also known (e.g. Ganf \& Oliver 1982).

Most marine biologists concerned with the dynamics of phytoplankton communities have traditionally focussed on seasonal aspects of the structure of phytoplankton assemblages (e.g. Smayda 1980). As stressed by Marrase et al. (1989), a distinction should be made between seasonal and bloom patterns of phytoplankton succession. During blooms, phytoplankton communities are subjected to growth sequences on temporal scales of days to weeks.

The result of the present study revealed a nonrandom occurrence of 3 successive groups during the spring bloom light-limited phase in the Baltic Sea. First, autotrophic nanoflagellates (Cryptomonas spp., Pyramimonas spp.) which are abundant in pre-bloom water prevailed, since stabilization of the upper layer is not a definite precondition for their growth. On the contrary, they seem to be favored by turbulent conditions in the thick UML. The second group can be considered as introductory for the spring bloom species (Chaetoceros holsaticus, $C$. wighamil, Thalassiosira levandeni), whose growth requires a weak or developing stability provided by hydrodynamic mechanisms (e.g. advection of lower-salinity water). The third group consists of species requiring better light conditions (e.g. Achnanthes taeniata). Their rapid growth is triggered by the shoaling of the UML to at least 20 to $30 \mathrm{~m}$ (depending on actual incoming irradiation). 
Because of the large-scale differences in the Baltic Sea upper-water-column structure (e.g. Alenius \& Leppäranta 1982) and the discontinuous distribution of different water properties due to quasi-stationary fronts, related to the general circulation patterns (e.g. Elken et al. 1987, Pavelson 1988), the phytoplankton species growth sequences during the vernal bloom may also be reflected in the large-scale spatial pattern of the phytoplankton communities. Although not exactly the same locations were covered in the 2 consecutive years (see Fig. 1) and considerable differences in the evolution of the spring bloom in 1985 and 1986 were found (Kahru \& Nommann 1990), the spatial distribution of phytoplankton assemblages was almost the same for all sections. Thus, the spatio-temporal distribution of consecutive phases from the less stratified central parts towards the strongly stratified nearshore regions, split up by quasi-stationary fronts, is a common phenomenon for the entire Baltic during the vernal bloom period.

Of special interest is the occurrence of high numbers of photosynthetic nanoflagellates in the upper deeply mixed layer before the outbreak of diatoms. As observed by Niemi \& Åström (1987), nanoflagellates may be very abundant during the peaks after the break-up of the ice (e.g. Pyramimonas spp., $7 \times 10^{6}$ cells $^{-1}$ in the Gulf of Finland in early May). Pronounced dominance of smaller chlorophyll-containing particles shortly before the onset of the diatom bloom has also been observed in the open Baltic proper (Kahru \& Nômmann 1990). It appears that, unlike diatoms, nanoflagellates are capable of maintaining themselves in the photic zone even under well-mixed conditions, which is consistent with earlier observations in other marine areas (Malone \& Chervin 1979, Levasseur et al. 1984), or that they have a lower compensation irradiance (Takahashi et al, 1978). However, one should be careful not to interpret this result as implying complete independence of nanoflagellates from stratification conditions.

Spatially averaged dynamics of different particle size groups during the vernal bloom in the central Baltic revealed a rapid disappearance of higher concentrations of smaller particles ( 2 to $4 \mu \mathrm{m}$ ) after their peak shortly before the outbreak of the massive diatom bloom (Fig. 7C in Kahru \& Nômmann 1990, p. 343). Coincidence of the spring protozooplankton maximum with that of vernal phytoplankton has been reported from coastal areas (Smetacek 1981) as well as from the open northern Baltic proper (Leppänen \& Bruun 1986). The likeliest food items of ciliates have been found to be nanoflagellates (Smetacek et al. 1980, Leppänen \& Bruun 1986). Johannes (1965) has shown that protozoan feeding increased remineralization rates in cultures, and Sieburth et al. (1978) have pointed out a difference in the ecological impact of protozoo- plankton vs metazooplankton grazing. As argued by Smetacek et al. (1980), feeding on nanoflagellates by protozooplankton leads to a short-term disruption of the food web structure, and essential elements tied up in ciliate biomass are rapidly returned to the system. Leppänen \& Bruun (1986) estimated that ca $25 \%$ of the particulate primary production during the spring bloom was cycled through heterotrophic ciliates in the open northern Baltic proper.

It appears that in the pelagic food web the nanoplanktonic (microbial?) loops begin considerably earlier than does the diatom vernal bloom itself. Recent investigations by Kahru \& Nômmann (1990) have shown that salinity stratification plays a major role in triggering the spring bloom. But, in the upper layers, the same salinity stratification which provides the necessary stability for phytoplankton growth can be expected to prevent thermal deep convection (typical of lakes), previously considered as the main mechanism for upward transport of nutrients from below the euphotic zone (e.g. Sjöberg \& Wilmot 1977, Stigebrandt \& Wulff 1987). Thus no consumption of the large nutrient reserves above the main halocline in the intermediate layers will take place. However, inertial and subinertial oscillations generating inhomogeneities in the vertical structure of the water column may also lead to the opening of the pycnocline on the surface (frontal upwellings, eddy peripheries, etc.; see Fig. 8). Besides, stronger wind events may result in intensive vertical wave mixing and entrainment, leading eventually to well-mixed water bodies down to the perennial halocline. In both cases nutrients will be transported to the euphotic zone, but in these local regimes the diatom. bloom is impeded by the intensive vertical mixing. Following this line of argumentation, there are strong reasons to believe that small autotrophic flagellates, with their rapid growth rate and relative independence from water-column stability, fill an important ecological 'niche', providing an additional path for the incorporation of nutrients into organic matter and subsequent recycling via the flagellate-ciliate food web.

Acknowledgements. Inspiring discussions with Dr Fredrik Wulff as well as valuable comments by Prof. Bengt-Owe Jansson, Dr Lutz Postel, Dr Jorma Kuparinen and Kaisa Kononen, M.Sc, are gratefully acknowledged. The language checking by Ms Ida Ernquist is greatly appreciated.

\section{LITERATURE CITED}

Alasaarela, E. (1979: Phytoplankton and environmental conditions in central and coastal areas of the Bothnian Bay. Ann. Bot. Fenn. 16: 241-274

Alenius, P., Leppäranta, M. (1982). Statistical features of hydrography in the northern Baltic Sea. Proc. 13th Conf. Baltic Oceanogr., Helsinki 1: 95-104 
Berzins, I. (1932). Das Plankton der lettischen Terminfahrt im Frühjahr 1928. Folie zool. hydrobiol. Vol. 5

Bodungen, B. v., Bröckel, K. v., Smetacek, V., Zeitzschel, B. (1981). Growth and sedimentation of the phytoplankton spring bloom in the Bornholm Sea (Baltic Sea). Kieler Meeresforsch. 5: 49-60

Edler, L. (1979a). Recommendations for marine biological studies in the Baltic Sea. Baltic mar. Biologists 5: 1-38

Edler, L. (1979b). Phytoplankton succession in the Baltic Sea. Acta bot. fenn. 110:75-78

Elken, J., Talpsepp, L., Pavelson, J. (1987). Dynamics and distribution of water masses in the Southern Gotland basin (polygon studies). Proc. 15th Conf. Baltic Oceanogr. 1: $146-166$

Falkowski, P. G. (1984). Physiological responses of phytoplankton to natural light regimes. J. Plankton Res. 6: 295-307

Fennel, W., Lass, H. U., Seifert, T. (1986). Some aspects of vertical and horizontal excursion of phytoplankton. Ophelia (Suppl.) 4: 55-62

Ganf, G. G., Oliver, L. (1982). Vertical separation of light and available nutrients as a factor causing replacement of green algae in the plankton of a stratified lake. J. Ecol. 70 : $829-844$

Hobro, R. (1979). Annual phytoplankton successions in a coastal area in the Northern Baltic. In: Naylor, E., Hartnoll, R. G. (eds.) Cyclic phenomena in marine plants and animals. Pergamon Press, Oxford, p. 3-10

Holmes, R. W. (1970). The Secchi disk in turbid coastal waters. Limnol. Oceanogr. 15: 688-694

ICES (1989). Baltic Sea Patchiness Experiment - PEX '86. Dybern, B. I., Hansen, H. P. (eds.) Cooperative Research Report No. 163. Int. Coun. Explor. Sea, Copenhagen

Johannes, R. E. (1965). Influence of marine protozoa on nutrient regeneration. Limnol. Oceanogr. 10: 434-442

Kahru, M., Leppänen, J.-M., Nômmann, S., Passow, U., Postel, L., Schulz, S. (1990). Spatio-temporal mosaic of the phytoplankton spring bloom in the open Baltic Sea. Mar. Ecol. Prog. Ser. 66: 301-309

Kahru, M., Nômmann, S. (1990). The phytoplankton spring bloom in the Baltic Sea in 1985, 1986: multitude of spatiotemporal scales. Contin. Shelf Res. 10: 329-354

Kahru, M., Nômmann, S., Allikas, E. (1989). A system for determining the lateral distribution of plankton. Okeanologiya 4: 670-674 (in Russian)

Kahru, M., Nômmann, S., Simm, M., Vilbaste, K. (1986). Plankton distributions and processes in the Baltic boundary zones. In: Nihoul, J. C. J. (ed.) Marine interfaces ecohydrodynamics. Elsevier, Amsterdam, p. 273-293

Kaiser, W., Schulz, S. (1978). On the causes for the differences in space and time of the commencement of the phytoplankton bloom in the Baltic. Kieler Meeresforsch. (Sonderh.) 4: 161-170

Kell, V. (1981). Das Phytoplankton der Ostsee. Geod. geophys. Veröff. 4(33): 3-26

Knoechel, R., Kalff, J. (1978). An in situ study of the productivity and population dynamics of five freshwater planktonic diatom species. Limnol. Oceanogr. 23: $195-217$

Kononen, K., Nômmann, S., Hansen, G., Hansen, R., Breuel, G., Gupalo, E. (in press). Spatial heterogeneity and dynamics of vernal phytoplankton species in the Baltic Sea in April-May 1986. J. Plankton Res.

Leppänen, J.-M. (1988). Carbon and nitrogen cycles during the vernal growth period in the open northern Baltic proper. Meri 16: 1-118

Leppänen, J.-M., Bruun, J.-E. (1986). The role of pelagic ciliates including the autotrophic Mesodinium rubrum during the spring bloom of 1982 in the open northern Baltic proper. Ophelia (Suppl.) 4: 147-157

Levasseur, M., Therriault, J.-C., Legendre, L. (1984). Hierarchical control of phytoplankton succession by physical factors. Mar. Ecol. Prog. Ser. 19: 211-222

Malone, T. C., Chervin, M. B. (1979). The production and fate of phytoplankton size fractions in the plume of the Hudson River, New York Bight. Limnol. Oceanogr. 24: 683-696

Margalef, R. (1958). Temporal succession and spatial heterogeneity in phytoplankton. In: Buzzti-Traverso, A. A. (ed.) Perspectives in marine biology. University of California Press, Berkeley, p. 323-349

Margalef, R. (1967). The food web in the pelagic environment. Helgoländer wiss. Meeresunters. 15: 548-559

Marrase, C., Duarte, C. M., Vaque, D. (1989). Succession patterns of phytoplankton blooms: directionality and influence of algal cell size. Mar. Biol. 102: 43-48

Niemi, $\AA$. (1973). Ecology of phytoplankton in the Tvärminne area, SW coast of Finland. I. Dynamics of hydography, nutrients, chlorophyll a and phytoplankton. Acta bot. fenn. 100: $1-68$

Niemi, A. (1982). Dynamics of phytoplankton in the brackishwater inlet Pojoviken, southern coast of Finland. Hydrobiologia 86: $33-39$

Niemi, A., Åström, A.-M. (1987). Ecology of phytoplankton in the Tvärminne area, SW coast of Finland. IV. Environmental conditions, chlorophyll a and phytoplankton in winter and spring 1984 at Tvärminne Storfjärd. Ann. Bot. Fenn. 24: 333-352

Nikolaev, I. I. (1953). Phytoplankton of the Gulf of Riga. Trudy Latv. Otdel. VNIRO 1: 115-172 (in Russian)

Nikolaev, I. I. (1957). Biological seasons of the Baltic Sea. Trudy Latv. Otdel. VNIRO 2: 115-140 (in Russian)

Passow, U. (1989). Vertikalverteilung und Sedimentation von Phytoplanktonarten in cer mittleren Ostsee während des Frühjahres 1986. Ber. Inst. MeeresKde Kiel 192: 1-203

Pavelson, J. (1988). Nature and some characteristics of thermohaline fronts in the Baltic Proper. Proc. 16th Conf. Baltic Oceanogr. 2: 796-805

Piirsoo, K., Porgasaar, V. (1985). Peculiarities of the distribution, seasonal and annual dynamics of the phytoplankton and chlorophyll a content in Tallinn bay. In: Trei, T. (ed.) Problems concerning bioindication of the ecological conditions of the Gulf of Finland, Vol. 15. Acad. Sci. Estonian SSR, Inst. Zool. Bot., Hydrobiol. Res., Tallinn, p. $50-57$

Pingree, R. D., Holligan, P. M., Mardell, G. T., Head, R. N. (1976). The influence of physical stability on spring, summer, autumn phytoplankton blooms in the Celtic Sea. J. mar. biol. Ass. U.K. 56: 845-873

Poole, H. H., Atkins, W. R. G. (1929). Photoelectric measurements of submarine illumination throughout the year. J. mar. biol. Ass. U.K. 16: 297-324

Pugh, P. R. (1978). The application of particle counting to an understanding of the small-scale distribution of plankton. In: Steele, J. H. (ed.) Spatial pattern in plankton communities. Plenum Press, New York, p. 111-129

Purasjoki, K. (1947). Plankton gesammelt in den Jahren 1899-1910 an den Küsten Finnlands von K. M. Levander. Finnl. hydrogr-biol. Unters. 11: 1-50

Riley, G. A. (1942). The relationship of vertical turbulence and spring diatom flowerings. J. mar. Res. 5:67-87

Riley, G. A. (1957). Phytoplankton of the north central Sargasso Sea. Limnol. Oceanogr. 2: 252-270

Sambrotto, R. N., Niebauer, H. J., Goering, J. J., Iverson, R. L. (1986). Relationships among vertical mixing, nitrate up- 
take, and phytoplankton growth during the spring bloom in the southeast Bering Sea middle shelf. Contin. Shelf Res. 5: 161-198

Sieburth, J. M., Smetacek, V., Lenz, J. (1978). Pelagic ecosystem structure: heterotrophic compartments of the plankton and their relationship to plankton size fractions. Limnol. Oceanogr. 23: 1256-1263

Sjoberg, S., Wilmot, W. (1977). System analysis of a spring phytoplankton bloom in the Baltic. Contr. Askö Lab., Univ. Stock. 20: 1-99

Smayda, T. J. (1980). Phytoplankton species succession. In: Morris, I. (ed.) The physiological ecology of phytoplankton. University of California Press, Berkeley, p. 493-570

Smetacek, V. (1981). The annual cycle of protozooplankton in the Kiel Bight. Mar. Biol. 63: 1-11

Smetacek, V., Bodungen, B. v., Knoppers, B., Neubert, H.,

This article was submitted to the editor
Pollehne, F., Zeitzschel, B. (1980). Shipboard experiments on the effect of vertical mixing on natural plankton populations in the central Baltic Sea. Ophelia (Suppl.) 1: 77-98 Stigebrandt, A., Wulff, F. (1987). A model for the dynamics of nutrients and oxygen in the Baltic proper. J. mar. Res. 45 $729-759$

Takahashi, M., Barwell-Clarke, J., Whitney, F., Koeller, P. (1978). Winter conditions of marine plankton populations in Saanich Inlet, B. C., Canada. I. Phytoplankton and its surrounding environment. J. exp. mar. Biol. Ecol. 31: 283-301

Tilzer, M. M. (1988). Secchi disk-chlorophyll relationships in a lake with highly variable phytoplankton biomass. Hydrobiologia 162: 163-171

Välikangas, 1. (1926). Planktologische Untersuchungen im Hatengebiet von Helsingfors. I. Acta zool. fenn. 1: 1-298

Manuscript first received: February 26, 1991

Revised version accepted: March 19, 1992 